\title{
Misuse of Islamic Banking for Tax Evasion - Modaraba in Pakistan
}

\section{Christian Lorenz*}

Centre for Applied Economic Research, University of Muenster, Germany

Keywords: Modaraba; Pakistan; Islamic banking; Tax evasion

\section{Introduction}

Modern Islamic finance emerged from a belief that conventional forms of financing may contain elements prohibited by Sharia, since the Quran forbids taking interest. As an alternative, a myriad of Islamic financial transactions have been innovated based on a combination of classical trade-based contracts and other accompanying arrangements. These products are deemed to be in compliance with Sharia precepts, yet provide some level of economic parity with comparable forms of conventional financing [1].

Islamic finance has witnessed rapid expansion over the years and can now truly be considered a global industry both in terms geographical spread and assets class coverage. The IFSB estimates assets of the world Islamic financial industry to reach 1,600 billion USD along with revenues of approximately 120 billion USD by 2012 . Given that about $22 \%$ of the world population is Muslim, even a $1 \%$ contribution by IFIs towards global financial assets and deposits depicts a significantly untapped market [2].

\section{Modaraba Funds}

One of the risk areas in the tax legislation and tax administration of Pakistan being identified are large groups of taxpayers, which should be registered, but are not - due to the existence of unregistered income from Islamic Banking like Modaraba funds. Modaraba (alternative spellings are Mudharabah, Mudaraba or Mudhorabah) describe contracts of profit-sharing between a capital provider and an entrepreneur in which the former contributes the capital and the latter contributes his effort in managing the business. The parties will share the business profit according to an agreed ratio. However, if the business incurs loss, it shall be borne by the capital provider alone while the entrepreneur would have just wasted his time and efforts [3]. Contracts are applied in deposit taking arrangement such as current account, savings account and investment account. Modaraba contract is also applied in inter-banks investment and Islamic bonds. In a Modaraba contract, the capital providers may agree to limit the rate of return to a defined percentage whereby the excess can be given to the manager as an incentive or performance fee.

In Pakistan the Sharia Advisory Board (SAB) of the SECP is responsible to observe modarabas and other Islamic financial products under the light of Islamic instructions; $\mathrm{SAB}$ aims in regulating the range of Islamic financial products under the principles of the Sharia. According to $\mathrm{SAB}$ rules and regulations, no modaraba shall be in business if it is not in conformity with the injunctions of Islam and the registrar shall not permit the floatation of a modaraba unless the religious board has certified in writing that the modaraba is not a business opposed to the injunctions of Islam [4].

\section{Pakistan Market}

Also in Pakistan the Islamic banking industry continued its growth momentum during the last year. Both assets and deposits registered positive two digit quarterly growth and reached total assets of 837 billion PKR and deposits of 706b PKR. In terms of market shares, assets constitute $8.6 \%$ whereas deposits constitute $9.7 \%$ in the overall banking industry [5]. Most of the modarabas are providing financial services while a few are engaged in industrial (textile, energy and agriculture) and trading activities.

There are 5 full-fledged Islamic banks and 13 conventional banks which offer Islamic banking. In addition to banks offering Modaraba, independent Modaraba-Companies have been founded. The investor can buy a stake in an open investment fund or insurance fund with agreed profit sharing. For his fund participation he receives a 'Modaraba Certificate' which is freely tradable on the stock exchange. The Modaraba play an important role in the economy. At present 244 companies active in this economic area are registered with the SECP.

These companies hold substantial sums of money from Pakistanis and foreign investors. The income of the 'Modaraba societies' is free of income tax under the condition that they pay at least $90 \%$ of their annual profit to the certificate owners. Thus the largest part of these profits may at present go to the not tax-paying 'élite' of the country directly or hidden by tax shelter companies, registered in tax havens.

\section{Fake Islamic Mudaraba Companies}

The number of fake Islamic Modaraba companies is increasing in the country, which are depriving their depositors of billions of rupees while registered as Islamic banking industry, but who are following the conventional financial market like heavily investing in federal government securities through ijara sukuk instead of financing through the private sector [6]. Islamic Banking Institutions (IBIs) invested 267b PKR in government securities during the third quarter of this fiscal year, showing a growth of $74 \%$. Of a total of $267 \mathrm{~b}$ PKR investments, almost 50\% were provided by Islamic banks through ijara sukuk to the government for project financing.

\section{Conclusions}

The western debt crisis based on interest-based systems deepens Islamic finance's growth and should provide the industry with a sustained period of growth for the next decade. Deutsche Bank, a pillar of traditional banking, estimated in a recent report that Islamic Finance would almost double to $\$ 1.8$ trillion in assets by 2016 . Therefore the tax and regulatory environment for Islamic finance in Pakistan should be revised and modernized, not by guidelines but by strong, enforceable regulations and adjustments of the income tax ordinance that viewed the profits paid on Mudaraba as expenditure.

*Corresponding author: Christian Lorenz, Department of public administration Centre for Applied Economic Research, University of Muenster, Germany, Tel: +41 (0) 22799 6111; E-mail: christian.lorenz@gmx.ch.

Received December 15, 2014; Accepted April 30, 2015; Published May 08, 2015

Citation: Lorenz C (2015) Misuse of Islamic Banking for Tax Evasion - Modaraba in Pakistan. Review Pub Administration Manag 3: 151. doi:10.4172/2315-7844.1000151

Copyright: ( 2015 Lorenz C. This is an open-access article distributed under the terms of the Creative Commons Attribution License, which permits unrestricted use, distribution, and reproduction in any medium, provided the original author and source are credited. 
Citation: Lorenz C (2015) Misuse of Islamic Banking for Tax Evasion - Modaraba in Pakistan. Review Pub Administration Manag 3: 151. doi:10.4172/23157844.1000151

\section{References}

1. AOSSG (2011) Financial Reporting Issues relating to Islamic Finance.

2. GIFR (2011) Shaping Islamic finance together

3. AOSSG (2011) Financial Reporting Issues relating to Islamic Finance - part 2
4. Modarbas (2013) The fake modarbas. The daily times.

5. SBP (2012) Islamic Banking Bulletin .

6. The nation (2013) Fake Modaraba firms on the rise. 